\title{
Removal of ammonium from municipal wastewater with powdered and granulated metakaolin geopolymer
}

Tero Luukkonen, Kateřina Věžníková, Emma-Tuulia Tolonen, Hanna Runtti, Juho Yliniemi, Tao Hu, Kimmo Kemppainen \& Ulla Lassi

To cite this article: Tero Luukkonen, Kateřina Věžníková, Emma-Tuulia Tolonen, Hanna Runtti, Juho Yliniemi, Tao Hu, Kimmo Kemppainen \& Ulla Lassi (2017): Removal of ammonium from municipal wastewater with powdered and granulated metakaolin geopolymer, Environmental Technology

To link to this article: http://dx.doi.org/10.1080/09593330.2017.1301572

Accepted author version posted online: 01

Mar 2017.

Submit your article to this journal $₫$

View related articles ¿

View Crossmark data $₫$ 
Publisher: Taylor \& Francis \& Informa UK Limited, trading as Taylor \& Francis Group

Journal: Environmental Technology

DOI: $10.1080 / 09593330.2017 .1301572$

\section{Removal of ammonium from municipal wastewater with powdered and granulated metakaolin geopolymer}

Tero Luukkonen ${ }^{1}$, Kateřina Věžníková2 ${ }^{2}$ Emma-Tuulia Tolonen ${ }^{1,3}$, Hanna Runtti $^{3}$, Juho Yliniemi ${ }^{4}$, Tao $\mathrm{Hu}^{3}$, Kimmo Kemppainen ${ }^{1}$, Ulla Lassi ${ }^{3,5}$ 1 Kajaani University of Applied Sciences, Kuntokatu 5, FI-87101 Kajaani, Finland 2 Faculty of Chemistry, Brno University of Technology, Purkyňova 464/118, CZ-61200 Brno, Czech Republic

3 University of Oulu, Research Unit of Sustainable Chemistry, FI-90014 University of Oulu, Finland

4 University of Oulu, Fibre and Particle Engineering Research Unit, FI-90014 University of Oulu, Finland

5 University of Jyvaskyla, Kokkola University Consortium Chydenius, Unit of Applied Chemistry, Talonpojankatu 2B, FI-67100, Kokkola, Finlandepartment, University, City, Country

Telephone numbers and email addresses: Tero Luukkonen +358445353695, teroluuk@gmail.com, tero.luukkonen@kamk.fi; Kateřina Věžníková katerina.veznikova@gmail.com; Emma-Tuulia Tolonen +358294481617 emmatûulia.tolonen@oulu.fi; Hanna Runtti +358294481617 hanna.runtti@oulu.fi; Juho Yliniemi+358294482455 juho.yliniemi@oulu.fi; Tao Hu tao.hu@oulu.fi +35847166122; Kimmo Kemppainen +358447101050 kimmo.kemppainen@kamk.fi; Ulla Lassi+358294481592 ulla.lassi@oulu.fi

Corresponding author: Tero Luukkonen, teroluuk@gmail.com, tero.luukkonen@kamk.fi, +358445353695, orcid.org/0000-0002-1124-775X 


\section{Acknowledgements}

This work was supported by the Finnish Funding Agency for Innovation (TEKES) under Grant 4096/31/2014 (project GeoSorbents). The authors wish to thank Mr. Kai Tiihonen, Ms. Marjukka Hyyryläinen, and Dr. Esther Takaluoma for assisting with the laboratory work and analyses. 


\title{
Removal of ammonium from municipal wastewater with powdered and granulated metakaolin geopolymer
}

\begin{abstract}
Ammonium $\left(\mathrm{NH}_{4}{ }^{+}\right)$removal from municipal wastewater poses challenges with the commonly used biological processes. Especially at low wastewater temperatures, the process is frequently ineffective and difficult to control. One alternative is to use ion-exchange. In the present study, a novel $\mathrm{NH}_{4}{ }^{+}$ionexchanger, metakaolin geopolymer (MK-GP), was prepared, characterized, and tested. Batch experiments with powdered MK-GP indicated that the maximum exchange capacities were 31.79, 28.77, and $17.75 \mathrm{mg} / \mathrm{g}$ in synthetic, screened, and pre-sedimented municipal wastewater, respectively, according to the Sips isotherm $\left(R^{2} \geq 0.91\right)$. Kinetics followed the pseudo-second order rate equation in all cases $\left(\mathrm{k}_{\mathrm{p} 2}=0.04-0.24 \mathrm{~g} \mathrm{mg}^{-1} \mathrm{~min}^{-1}, \mathrm{R}^{2} \geq 0.97\right)$ and the equilibrium was reached within 30-90 min. Granulated MK-GP proved to be suitable for a continuous column mode use. Granules were high-strength, porous at the surface and could be regenerated multiple times with $\mathrm{NaCl} / \mathrm{NaOH}$. A bench-scale pilot test further confirmed the feasibility of granulated MK-GP in practical conditions at a municipal wastewater treatment plant: consistently $<4 \mathrm{mg} / \mathrm{L} \mathrm{NH}_{4}{ }^{+}$could be reached even though wastewater had low temperature (approx. $10^{\circ} \mathrm{C}$ ). The results indicate that powdered or granulated MK-GP might have practical potential for removal and possible recovery of $\mathrm{NH}_{4}{ }^{+}$from municipal wastewaters. The simple and low-energy preparation method for MK-GP further increases the significance of the results.
\end{abstract}

Keywords: Alkali activation; ammonium; geopolymer; ion exchange; municipal wastewater

\section{Introduction}

Ammonium $\left(\mathrm{NH}_{4}^{+}\right)$is the most important nitrogen-species contributing to the eutrophication of water bodies in the areas where nitrogen is the nutrient in shortest supply [1]. Consequently, nitrogen removal from municipal wastewater has become commonly mandatory and, for example, in Europe it is specified in the urban wastewater treatment directive [2]. The most widely used method to remove nitrogen 
from wastewater is by microbial nitrification-denitrification reactions which can be implemented by, for instance, the aerobic-anoxic active sludge process [3]. However, nitrification rate drops sharply as temperature of wastewater decreases and, consequently, nitrogen removal is challenging in cool and temperate climate areas during cold season [4].

Adsorption or ion-exchange-based approaches offer more robust alternative method for $\mathrm{NH}_{4}{ }^{+}$removal. It was recently demonstrated by a simulation that anaerobic digestion followed by zeolite-based ion-exchange had lower operational costs and better nitrogen-removal performance than the conventional nitrification-denitrification or the Anammox processes [5]. Furthermore, nitrogen and carbon could be recovered in the forms of marketable fertiliser and biogas, respectively [5]. However, it was emphasised that the exchange capacity of the ion-exchanger material has a crucial role in the overall process efficiency [5].

Recently, a novel $\mathrm{NH}_{4}{ }^{+}$ion-exchanger material was developed: metakaolin geopolymer [6]. The main advantages are high $\mathrm{NH}_{4}{ }^{+}$exchange capacity; simple and low-energy synthesis; and low-cost and readily available raw materials [6].

Additionally, geopolymers have been studied for the adsorption of dyes [7-10], sulphate [11], As [12], Ca [13], Cd [14], Co [15,16], Cr [17,18], Cs [19-21], Cu [22-25], Ni [12,26], Pb [13,17,27,28], Sb [12], Sr [19] and Zn [17]. Geopolymers consist of an anionic framework of corner-sharing $\mathrm{SiO}_{4}$ and $\mathrm{AlO}_{4}$ where the exchangeable cations are located in the voids - similarly as with zeolites [29]. The anion (such as arsenic or sulphate) removal with geopolymers is based on modification or formation of secondary mineral phases $[11,12]$. However, unlike zeolites, geopolymers are amorphous. The most common synthesis method involves a reaction between aluminosilicate raw material (such as metakaolin) and alkali activator (commonly concentrated sodium 
hydroxide and silicate) at ambient or near-ambient temperature and pressure [30]. The formation reactions of geopolymers include dissolution, gelation, reorganisation, and hardening although the exact mechanism remains still unclear [31].

Geopolymerisation-granulation is a new method by which spherical geopolymer granules can be produced [32]. In short, the precursor particles are mixed inside a high shear granulator and as the alkali activator is added slowly on the particle flow, the particles begin to bind together by the surface tension of the liquid. In addition, the alkali activator starts to dissolve the precursor particles which enhance the binding. As the process continues, larger and larger granules will form. The process is stopped once the desired granule size is achieved and the granules left to harden to increase their strength.

Zeolites, synthetic and natural, have been studied extensively for the removal and recovery of $\mathrm{NH}_{4}{ }^{+}$from various wastewaters [33-36]. Metakaolin geopolymer was earlier noted as a more efficient $\mathrm{NH}_{4}{ }^{+}$adsorbent than typical natural zeolites in terms of capacity and kinetics [6]. However, metakaolin geopolymer has not been tested in municipal wastewater and, in fact, almost all of the aforementioned other geopolymer adsorbent studies have been performed with synthetic wastewaters (i.e., salts in distilled water) as well.

Consequently, the objective of the present study was to test metakaolin geopolymer in both synthetic and municipal wastewaters for $\mathrm{NH}_{4}{ }^{+}$removal using batch and continuous modes. Metakaolin geopolymer was prepared using a novel and easily scalable process: geopolymerisation-granulation. Prepared granules were characterized for their physico-chemical properties. The regenerability of the spent geopolymer was assessed. In order to confirm the feasibility of $\mathrm{NH}_{4}{ }^{+}$removal with metakaolin 
geopolymer in practical conditions, a bench-scale pilot study was performed at a wastewater treatment plant.

\section{Materials and methods}

\section{Synthesis of geopolymers}

Powdered geopolymer was synthesised by mixing metakaolin with alkali activator in a liquid to solid weight ratio (L/S) of 1.0 for five minutes, allowed to consolidate at ambient temperature for three days, crushed to particle size of 63-125 $\mu \mathrm{m}$, washed with deionised water, and stored in a desiccator before use. Alkali activator contained $12 \mathrm{M}$ sodium hydroxide (VWR Chemicals) and sodium silicate $\left(\mathrm{Na}_{2} \mathrm{O} 8.2-9.2 \% \mathrm{w} / \mathrm{w}, \mathrm{SiO}_{2}>\right.$ $27.7 \% \mathrm{w} / \mathrm{w}, \mathrm{VWR}$ Chemicals) in a weight ratio of 1.2 .

Granulated geopolymer was formed by mixing metakaolin powder in a high shear granulator (Eirich EL1) and dosing the alkali activator drop-wise until an L/S ratio of 0.4 was reached. This L/S ratio was the maximum before agglomeration of granules started to occur. After granulation, the particle sizes of 1-4 mm (for laboratory column experiments) or 1-6 mm (for field experiment) were separated by sieving, granules were allowed to consolidate for three days, and material was washed with deionised water before use.

\section{Characterisation of geopolymers}

The composition of granule cross-sections were determined by FE-SEM-EDS (field emission scanning electron microscopy with energy dispersive X-ray spectrometer) using Zeiss Ultra plus instrument with Oxford Instruments INCA system EDS software. Prior the FE-SEM-EDS analysis, granules were cast in epoxy resin and polished to reveal the cross-section. Compressive strength of granules was determined with Zwick Roell Z010 instrument. Loose bulk density $\left(\rho_{\mathrm{b}}\right)$, percentage of voids $(v)$, apparent 
particle density $\left(\rho_{\mathrm{a}}\right)$, oven-dried particle density $\left(\rho_{\mathrm{rd}}\right)$, saturated and surface-dried particle density $\left(\rho_{\mathrm{ssd}}\right)$ and water absorption $\left(\mathrm{WA}_{24}\right)$ were determined with Equations 16, respectively, according to standard methods $[37,38]$.

$\rho_{b}=\frac{m_{2}-m_{1}}{V}$

$v=\frac{\rho_{r d}-\rho_{b}}{\rho_{r d}} \times 100$

$\rho_{a}=\rho_{w} \frac{M_{4}}{M_{4}-\left(M_{2}-M_{3}\right)}$

$\rho_{r d}=\rho_{w} \frac{M_{4}}{M_{1}-\left(M_{2}-M_{3}\right)}$

$\rho_{s s d}=\rho_{w} \frac{M_{1}}{M_{1}-\left(M_{2}-M_{3}\right)}$

$W A_{24}=\frac{100 \times\left(M_{1}-M_{4}\right)}{M_{4}}$

where $\mathrm{m}_{2}=$ mass of the container and test specimen [kg], $\mathrm{m}_{1}=$ empty container $[\mathrm{kg}], \mathrm{V}$ $=$ volume of the container $\left[\mathrm{m}^{3}\right], \rho_{\mathrm{w}}=$ density of water $\left[\mathrm{kg} / \mathrm{m}^{3}\right], \mathrm{M}_{1}=$ the mass of the saturated and surface-dried aggregate in the air [g], $\mathrm{M}_{2}=$ the apparent mass in water of the basket containing the sample of saturated aggregate [g], $\mathrm{M}_{3}=$ the apparent mass in water of the empty basket [g], and $\mathrm{M}_{4}=$ the mass of the oven-dried test portion in air [g].

\section{Laboratory-scale $\mathrm{NH}_{4}^{+}$removal experiments}

Two wastewater samples were collected from a municipal wastewater treatment plant (Oulu, Finland): 1) after aerated sand removal and screening (referred to as screened effluent) and 2) after aerated sand removal, screening, coagulation with polyaluminium chloride, and sedimentation (referred to as pre-sedimented effluent). The effects of powdered adsorbent dose (0.5-25 g/L, 24 h contact time) and contact time (1-1440 min, dose $5 \mathrm{~g} / \mathrm{L}$ ) were studied. Similar experiments were performed also with model solution prepared of ammonium chloride (Merck). The effect of $\mathrm{NH}_{3}-\mathrm{NH}_{4}{ }^{+}$equilibrium on the 
removal was studied by adjusting the model solution $\mathrm{pH}$ in the range of 3-10 without sorbent, mixing for $24 \mathrm{~h}$, and comparing to the results obtained with sorbent. After each experiment, geopolymer powder was separated by centrifuging and the supernatant was analysed for $\mathrm{NH}_{4}{ }^{+}$concentration using a flow injection analyser (Foss-Tecator Fiastar 5000).

Isotherm and kinetics models were applied to the data obtained in the batch experiments with powdered adsorbent. Several isotherms were applied and the bestfitting was the Sips isotherm [39] (Equation 7).

$q_{e}=\frac{q_{m}\left(b C_{e}\right)^{n}}{1+\left(b C_{e}\right)^{n}}$

where $\mathrm{q}_{\mathrm{e}}(\mathrm{mg} / \mathrm{g})$ is the equilibrium sorption amount; $\mathrm{q}_{\mathrm{m}}(\mathrm{mg} / \mathrm{g})$ corresponds to the maximum sorption capacity; b $(\mathrm{L} / \mathrm{mg})$ is a parameter related to the energy of sorption; $\mathrm{C}_{e}(\mathrm{mg} / \mathrm{L})$ is the equilibrium concentration of $\mathrm{NH}_{4}^{+}$, and the exponent $\mathrm{n}$ (dimensionless) describes the heterogeneity of the sorbent surface. The kinetics data was best described using the pseudo-second order rate equation [40] (Equation 8) which can be integrated with the condition $q_{t}=0$ when $t=0$ (Equation 9).

$\frac{d q_{t}}{d t}=k_{p 2}\left(q_{e}-q_{t}\right)^{2}$

$\frac{t}{q_{t}}=\frac{1}{k_{p 2} q_{e}^{2}}+\frac{t}{q_{e}}$

where $\mathrm{q}_{\mathrm{t}}(\mathrm{mg} / \mathrm{g})$ is the sorption amount at time $\mathrm{t}(\mathrm{min}), \mathrm{k}_{\mathrm{p} 2}(\mathrm{~g} /(\mathrm{mg} \times \mathrm{min})$ is the pseudosecond order rate constant.

Continuous experiments were performed by weighing $50 \mathrm{~g}$ of granules (1-4 $\mathrm{mm}$ ) into a plastic column (inner height $99 \mathrm{~mm}$, width $44 \mathrm{~mm}$, and volume $0.15 \mathrm{~L}$ ), washing with deionised water, and pumping pre-sedimented effluent through the 
column using flow rates of 0.5 and $1.0 \mathrm{~L} / \mathrm{h}$ corresponding to 3 and 6 min empty bed contact time (EBCT), respectively. EBCT was calculated according to Equation 10:

$E B C T=\frac{V_{m}}{Q}$

where $V_{m}(L)$ is the volume of particles in the bed and Q $(L / h)$ is the volumetric flow rate.

Samples were taken with 15 min interval and $\mathrm{NH}_{4}{ }^{+}$was determined as described earlier. After filtration, the bed was flushed with $8 \mathrm{~L}$ of deionised water. Regeneration of filter bed was performed by pumping $2 \mathrm{~L}$ of $0.1 \mathrm{M} \mathrm{NaOH}$ and $0.2 \mathrm{M} \mathrm{NaCl}$ solution through the column using $2 \mathrm{~L} / \mathrm{h}$ flow rate and rinsing with $8 \mathrm{~L}$ of deionised water. Regeneration was performed two times and the $\mathrm{NH}_{4}{ }^{+}$removal performance was tested after each regeneration cycle.

Mass transfer resistance in the column experiments was assessed according to the method described by Fulazzaky et al. [41]. In short, the internal or porous $\left(\left[\mathrm{k}_{\mathrm{L}} \mathrm{a}\right]_{\mathrm{d}}\right)$, external or film $\left(\left[\mathrm{k}_{\mathrm{L}} \mathrm{a}\right]_{\mathrm{f}}\right)$, and global $\left(\left[\mathrm{k}_{\mathrm{L}} \mathrm{a}\right]_{\mathrm{g}}\right)$ mass transfer coefficients $(1 / \mathrm{h})$ were determined with equations $11-13$, respectively. These variables were then plotted against the percentage of outflow from the column and the curves were then used to determine whether the mass transfer resistance is dependent on internal or external diffusion.

$\left[k_{L} a\right]_{d}=\left[k_{L} a\right]_{g}-\left[k_{L} a\right]_{f}$

$\left[k_{L} a\right]_{g}=e^{B \beta+\ln \left(\ln \left(\frac{C_{O}}{C_{t}}\right)\right)}$

$\left[k_{L} a\right]_{f}=\left[k_{L} a\right]_{g} \times e^{-\beta \times \ln q_{c}}$

where B $(\mathrm{mg} / \mathrm{g})$ is potential mass transfer index relating to the driving force of mass transfer, $\beta((\mathrm{g} \times \mathrm{h}) / \mathrm{mg})$ is adsorbate-adsorbent affinity parameter, $\mathrm{C}_{0}(\mathrm{mg} / \mathrm{L})$ and $\mathrm{Ct}$ (mg/L) are initial $\mathrm{NH}_{4}{ }^{+}$concentration and concentration at time $\mathrm{t}(\mathrm{h})$, and $\mathrm{q}_{\mathrm{c}}(\mathrm{mg} / \mathrm{g})$ is the 
cumulative adsorbed amount of $\mathrm{NH}_{4}^{+}$on granules. $\mathrm{B}$ and $\beta$ were determined from the intercept and slope, respectively, by plotting $\ln \mathrm{q}_{\mathrm{c}}$ versus $\ln \mathrm{t}$ according to Equation 14 . $\ln q_{c}=B+1 / \beta \times \ln t$

\section{Pilot-scale $\mathrm{NH}_{4}{ }^{+}$removal experiment}

A small pilot-scale experiment was performed on-site at a municipal wastewater treatment plant (Jämsä, Finland). The wastewater treatment plant process consists of pre-treatment (screening, sand/grease separation, and pre-sedimentation), secondary treatment (active sludge process and post-sedimentation), and tertiary treatment (flotation and UV disinfection). Side-flow of treated wastewater $(0.2 \mathrm{~L} / \mathrm{min})$ after UV disinfection was pumped with a submersible pump through a stainless steel filter (inner diameter $105 \mathrm{~mm}$, height $600 \mathrm{~mm}$ and volume 5.20 L) filled with 2114g (approximately 3.2 L) of geopolymer granules (particle size 1-6 mm) (for experimental set-up, see Figure 6). After the filter, treated water was sampled with an interval of $1 \mathrm{~h}$ using an automatic sampler. The influent water to the filter was sampled manually several times per day. $\mathrm{NH}_{4}{ }^{+}$removal was monitored semiquantitatively on-site using a photometer (Chemetrics V-2000) and cuvette tests (Chemetrics Vacu-Vials K1403) which measures free ammonia and monochloramine [42]. The samples taken with automatic sampler were analysed quantitatively for $\mathrm{NH}_{4}{ }^{+}$with a flow injection analyser (Foss-Tecator Fiastar 5000). Regeneration was performed by first flushing the filter bed with clean water, pumping $25 \mathrm{~L}$ of $0.1 \mathrm{M} \mathrm{NaOH}$ and $0.2 \mathrm{M} \mathrm{NaCl}$ solution through the filter, and rinsing with clean water until the effluent had low residual $\mathrm{NH}_{4}{ }^{+}$. 


\section{Results and discussion}

\section{Characteristics of metakaolin geopolymer}

Detailed characteristics of the metakaolin geopolymer powder are presented elsewhere [6]. In short, metakaolin geopolymer is X-ray amorphous and has higher specific surface area and is more porous than metakaolin. Infrared spectrum, ${ }^{27} \mathrm{Si}$ and ${ }^{29} \mathrm{Al} \mathrm{MAS}-$ NMR (magic angle spinning nuclear magnetic resonance) spectra indicate a change of chemical structure of metakaolin after geopolymerisation. Zeta potential of metakaolin geopolymer is negative when $\mathrm{pH}>4$.5. The negative zeta potentialindicates affinity towards cations.

The cross-section of a granule (Figure 1) shows that the core (diameter of approx. $2 \mathrm{~mm}$, highlighted with white) is denser than the porous surface layer (approx. $0.5 \mathrm{~mm})$. The porous nature of granules is also demonstrated by the high volume of voids: 57.9\% (Table 2). However, there are no clear differences in the chemical composition (Table 1) across the granule indicating that geopolymerisation reaction has taken place uniformly.

Figure 1. Cross section of metakaolin geopolymer granule. The results of point analysis are shown in Table 1 . The inner denser core has been highlighted with white colour.

Table 1. Semi-quantitative energy dispersive spectrum (EDS) analysis of points shown in Figure 1.

Physical properties of granules are shown in Table 2. Compressive strength of granules could not be measured in $\mathrm{N} / \mathrm{m}^{2}$ (i.e. Pa) due to their spherical size: instead, the force $(\mathrm{N})$ needed to break granules is given. Compressive strength gives an indication of granule quality: the obtained granules had an average strength of 63.85 N. However, there was a 
large variation between individual $1-4 \mathrm{~mm}$ sized granules $(34-123 \mathrm{~N}, \mathrm{n}=11)$. The strength development is due to the formation of bridges between particles. It has been noted that the plate-shapes of metakaolin particles [43] might hinder granulation and (high) strength development [32]. Furthermore, the use of potassium hydroxide and silicate enhances the strength development [32]. However, based on the performed filtration experiments, the obtained strength appears to be sufficient.

Table 2. Physical properties of metakaolin geopolymer granules (1-4 mm).

\section{$\mathrm{NH}_{4}{ }^{+}$removal with powdered metakaolin geopolymer: batch experiments}

The differences in the $\mathrm{NH}_{4}{ }^{+}$removal efficiency from screened, pre-sedimented, and synthetic wastewater are small: in all cases up to approx. 90\% removal is reached (Figure 2). This indicates that the geopolymer is selective towards $\mathrm{NH}_{4}{ }^{+}$and wastewater physico-chemical characteristics (Table 3) have only a minor effect on the removal efficiency. The increase of geopolymer powder dose (Figure 2A) up to approx. 4 g/L increases $\mathrm{NH}_{4}{ }^{+}$removal results significantly but with larger doses the removal levels-off at $85-90 \%$. The equilibrium-state is reached after 30-90 min (Figure 2B). The rapid adsorption has been explained to occur on the surface of the adsorbent whereas the slower adsorption occurs inside the pores [44]. It has been shown that dosing of zeolite powder to the activated sludge process has a beneficial effect on nitrogen removal; zeolite acts as ion-exchager, biofilm carrier and could be regenerated continuously by microbes; and only a small additional dosing of zeolite is necessary to replace zeolite loss due the sludge excluding $[45,46]$. Since metakaolin geopolymer represents natural zeolite chemically, a similar process could be applied with geopolymer powder. In fact, geopolymer made of mine waste mud was found as a potential carrier media for fixedfilm wastewater-treatment processes [47]. 
Figure $2 . \mathrm{NH}_{4}{ }^{+}$removal results from screened, pre-sedimented, and synthetic wastewater: A) effect of geopolymer powder dose and B) effect of contact time. Initial $\mathrm{NH}_{4}{ }^{+}$was 32, 39, and $40 \mathrm{mg} / \mathrm{L}$ in synthetic, pre-sedimented and screened wastewater, respectively.

Table 3. Physico-chemical characteristics of synthetic, pre-sedimented and screened wastewaters.

Based on the data presented in Figure 2A, isotherm fitting was performed. Several isotherms were applied and the best-fitting model was the Sips isotherm and thus only its data is shown. Similarly, the best-fitting kinetics model was the pseudo-second order rate equation. The parameters obtained from isotherm and kinetics modelling are shown in Table 4 . The maximum sorption capacity $\left(\mathrm{q}_{\mathrm{m}}\right)$ is higher than typically reported for natural zeolites although some synthetic zeolites haye still a higher capacity [6]. Lower $\mathrm{Si} / \mathrm{Al}$ ratio increases adsorption capacity as there is more negative charge in the alumino-silicate framework and subsequently more exchangeable cations: metakaolin geopolymer has a lower Si/Al ratio than typical natural zeolites. The maximum capacity is only slightly reduced when comparing synthetic wastewater and screened effluent. However, a significant decrease of $\mathrm{q}_{\mathrm{m}}$ is observed with the pre-sedimented effluent. This could be due to the addition of flocculant and $\mathrm{pH}$ adjustment chemicals: for example, calcium concentration ( $45 \mathrm{mg} / \mathrm{L}$ ) is higher than with the screened effluent (27 $\mathrm{mg} / \mathrm{L}$ ) (see Table 2). Also with the kinetics, the trend of rate constants is the same: synthetic wastewater $>$ screened effluent $>$ pre-sedimented effluent. Calculated and experimental capacity values from isotherm and kinetics modelling $\left(\mathrm{q}_{\mathrm{m}}\right.$ and $\mathrm{q}_{\mathrm{e}}$, respectively) are in agreement.

Table 4. The obtained parameters of isotherm and kinetics models. 
Due to the alkaline synthesis conditions, metakaolin geopolymer increases $\mathrm{pH}$ even after careful rinsing (Figure 3A). This property of geopolymers was recently utilised in $\mathrm{pH}$ buffering of anaerobic digestion [48]. The increase of $\mathrm{pH}$ is pronounced in synthetic wastewater due to the lack of $\mathrm{pH}$ buffering capacity. However, with the well-buffered real wastewater effluents, $\mathrm{pH}$ increases significantly only when the dose of sorbent is larger than $5 \mathrm{~g} / \mathrm{L}$. A blank experiment without dosing geopolymer but increasing $\mathrm{pH}$ with $\mathrm{NaOH}$ was conducted to see the contribution of $\mathrm{pH}$ change and possible volatilisation of $\mathrm{NH}_{3}$ gas on the $\mathrm{NH}_{4}{ }^{+}$removal. The results of the blank experiment (not shown) indicated that $\mathrm{NH}_{3}$ volatilisation started to contribute when $\mathrm{pH}$ was larger than 9 as suggested by the dissociation constant of ammonia: $\mathrm{pK}_{\mathrm{a}}=9.25$ at $25^{\circ} \mathrm{C}$ (Figure 3B) [49]. However, the contribution of volatilisation was rather minor (max. 6 \% removal) up to $\mathrm{pH}$ 11. Consequently, the volatilisation of $\mathrm{NH}_{3}$ has some effect on the removal of $\mathrm{NH}_{4}{ }^{+}$from synthetic wastewater but only a minor effect in the case of municipal wastewater in the present experimental set-up.

Figure 3. A) change of $\mathrm{pH}$ as a result of sorbent dose in synthetic wastewater, screened effluent and pre-sedimented effluent and B) speciation of $\mathrm{NH}_{4}{ }^{+}$and $\mathrm{NH}_{3}$ (calculated with MineQL+).

\section{$\mathrm{NH}_{4}{ }^{+}$removal with geopolymer granules: continuous laboratory-scale column experiments}

Metakaolin geopolymer granules were tested in column experiments using the presedimented effluent. These tests were used to preliminarily determine the effect of empty bed contact time (EBCT): the increase of EBCT from 3 to 6 min increases the $\mathrm{NH}_{4}{ }^{+}$removal 10-20 percentage points (Figure 4A). The breakthrough point (removal less than 50\%) with EBCT of 6 min occurs at approx. 180 min (corresponding $1.56 \mathrm{~L}$ outflow) and with EBCT of 3 min the removal is already $\leq 50 \%$ from the beginning. 
The regeneration was performed with $0.1 \mathrm{M} \mathrm{NaOH}$ and $0.2 \mathrm{M} \mathrm{NaCl}$ solution and the regenerated granules were used in column experiment again using 6 min EBCT (Figure 4B). The regeneration cycle was repeated twice. The regeneration was successful although the successive regeneration cycles decreased the $\mathrm{NH}_{4}{ }^{+}$removal. However, at the beginning of the 2nd cycle (after the first regeneration) $\mathrm{NH}_{4}{ }^{+}$removal was more efficient than with virgin metakaolin geopolymer for approx. $1 \mathrm{~h}$.

Figure 4. Continuous column experiments with pre-sedimented effluent: A) using empty bed contact times (EBCT) of 6 and 3 min; B) regeneration experiments. The initial $\mathrm{NH}_{4}{ }^{+}$was $35.7 \mathrm{mg} / \mathrm{L}$ on average.

Mass transfer in granulated metakaolin geopolymer during the column test was evaluated using the data from the series employing 6 min EBCT (Figure 4A). The plot of $\ln \mathrm{q}_{\mathrm{c}}$ versus $\ln \mathrm{t}$ gives a straight line with a good correlation: $\mathrm{R}^{2}>0.99$ (Figure 5A). Consequently, B and $1 / \beta$ can be reliably obtained from the intercept and slope, respectively (their numerical values are shown in Figure 5A). Figure 5B shows the variation of external, internal and global mass transfer coefficients as a function of percentage of outflow. As the granules approach saturation, the mass transfer coefficients approach zero. The porous or internal diffusion coefficient, $\left[\mathrm{k}_{\mathrm{L}} \mathrm{a}\right]_{\mathrm{d}}$, has negative values and thus it can be concluded that the mass transfer resistance is dependent on internal diffusion [41]. For powdered metakaolin geopolymer, the ratelimiting step in the $\mathrm{NH}_{4}^{+}$exchange process was the film diffusion as shown in our earlier study [6].

Figure 5. A) Plot of $\ln \mathrm{q}_{\mathrm{c}}$ versus $\ln \mathrm{t}$ and $\mathrm{B}$ ) plot of mass transfer factor (external, internal, and global) as a function of percentage of outflow. 


\section{$\mathrm{NH}_{4}^{+}$removal with geopolymer granules: pilot-scale experiment}

Target of the field experiment (Figure 6) was to test whether metakaolin geopolymer granules could, in practical conditions, reduce $\mathrm{NH}_{4}{ }^{+}$to a level less than $4 \mathrm{mg} / \mathrm{L}$ which is the common discharge limit in Finland for municipal wastewater treatment plants during the warm season (wastewater temperature $>12^{\circ} \mathrm{C}$ ). Secondly, the possibility to regenerate metakaolin geopolymer granules was tested in practice. The influent water to the filter had $\mathrm{NH}_{4}{ }^{+}$concentration of 15-20 mg/L (Figure 7). The characteristics of wastewater as reported by the wastewater treatment plant are shown in Table 5. During the pilot, the $\mathrm{NH}_{4}{ }^{+}$concentration was slightly lower than typically which was caused by heavy raining. Wastewater is very suitable for treatment with metakaolin geopolymer which is indicated by low suspended solids, $\mathrm{BOD}_{7, \mathrm{atu}}, \mathrm{COD}_{\mathrm{Cr}}$, and the amount of competing ions. Furthermore, the nitrification rate is low, i.e. most of nitrogen is present as $\mathrm{NH}_{4}{ }^{+}$in the effluent, and therefore it would be possible to reach also the $15 \mathrm{mg} / \mathrm{L}$ total-N limit set by the EU urban wastewater directive [2].

The results of the field experiment (Figure 7) demonstrate that the discharge limit of $4 \mathrm{mg} / \mathrm{L} \mathrm{NH}_{4}{ }^{+}$could be readily reached with the used set-up (flowrate $0.2 \mathrm{~L} / \mathrm{min}$ and the amount of 1-6 mm geopolymer granules $2114 \mathrm{~g}$ or $3.2 \mathrm{~L}$ ). The temperature of wastewater during field test was approx. $10^{\circ} \mathrm{C}$ which indicates that the ion-exchangebased treatment could be a feasible treatment option during the cold season. After $25 \mathrm{~h}$ of run, the filter was rinsed as there was accumulation of solids in the filter although suspended solids of influent were relatively low (Table 5). After $30 \mathrm{~h}$ of run, some breakthrough of $\mathrm{NH}_{4}{ }^{+}$started to occur and the $4 \mathrm{mg} / \mathrm{L}$ level was exceeded. However, the $\mathrm{NH}_{4}{ }^{+}$concentration again slowly decreased between 35-45 h of run time which could have been due to small changes in the influent concentration. The first regeneration was performed after $47 \mathrm{~h}$ of run. There was a peak of $\mathrm{NH}_{4}{ }^{+}$in the effluent after regeneration as the filter bed was rinsed. After regeneration (50-57 h of run), the 
$\mathrm{NH}_{4}{ }^{+}$concentration in the effluent slowly decreased. The on-site measurement of $\mathrm{NH}_{4}^{+}$ indicated again some breakthrough at $58 \mathrm{~h}$ and subsequently a second regeneration was performed. However, the laboratory measurements revealed that the concentration was still below $4 \mathrm{mg} / \mathrm{L}$ and the second regeneration was, in fact, unnecessary at this point. After the second regeneration, $\mathrm{NH}_{4}{ }^{+}$started to slowly decrease again: this could be due to the leaching of residual $\mathrm{NH}_{4}{ }^{+}$out of the geopolymer bed as the rinsing after regeneration was not possibly efficient enough. The used regenerant solution had $\mathrm{NH}_{4}^{+}$ concentration of $120 \mathrm{mg} / \mathrm{L}$ indicating that the studied process could be used to separate and concentrate $\mathrm{NH}_{4}{ }^{+}$. With further concentration and selection of different regeneration solution chemistry, the regenerant could be turned into a marketable nitrogen fertiliser (e.g. in the form of $\left.30 \%\left(\mathrm{NH}_{4}\right)_{2} \mathrm{SO}_{4}\right)$.

Figure 6. The set-up of $\mathrm{NH}_{4}^{+}$removal field experiment.

Figure 7. The results of $\mathrm{NH}_{4}^{+}$removal field experiment.

Table 5. Physico-chemical characteristics of wastewater treated in the pilot experiment three months before the pilot test (as reported by the wastewater treatment plant).

\section{Conclusions}

The present paper demonstrated that metakaolin geopolymer could be utilized in the removal and possibly recovery of $\mathrm{NH}_{4}{ }^{+}$from municipal wastewater. The maximum $\mathrm{NH}_{4}{ }^{+}$exchange capacity of powdered metakaolin geopolymer according to the Sips isotherm was $31.79,28.77$, and $17.75 \mathrm{mg} / \mathrm{g}$ in synthetic, screened, and pre-sedimented 
municipal wastewater, respectively. Up to approx. $90 \%$ removal of $\mathrm{NH}_{4}{ }^{+}$could be reached when the initial concentration was $32-40 \mathrm{mg} / \mathrm{L}$, dose $4 \mathrm{~g} / \mathrm{L}$ and contact time 60 min. The kinetics followed the pseudo-second order rate equation and rate constants followed the trend: synthetic wastewater $>$ screened effluent $>$ pre-sedimented effluent. Equilibrium was reached between 30-90 min. Geopolymerisation-granulation proved to be a suitable and easily scalable process for producing granulated metakaolin geopolymer. Granules had sufficient strength, porous surface, and could be regenerated with $\mathrm{NaCl} / \mathrm{NaOH}$. However, there was some decrease in the exchange efficiency already during two regeneration cycles. The mass transfer resistance in the continuous column mode was determined to be due to internal diffusion. A bench-scale pilot experiment was performed at a municipal wastewater treatment plant with tertiary effluent in order to study the feasibility of granulated geopolymers in practical conditions. $\mathrm{NH}_{4}{ }^{+}$concentration less than $4 \mathrm{mg} / \mathrm{L}$ could be consistently reached and regeneration was effective although wastewater temperature was only approx. $10^{\circ} \mathrm{C}$. Metakaolin geopolymer might be interesting over zeolites due to the following reasons: it has higher capacity than typical natural zeolites; it is less energy intensive to produce than synthetic zeolites; and no reserves of natural zeolites are available in the Northern Scandinavia, for example, whereas geopolymers could be prepared from locally available materials.

\section{Rerefences}

[1] Wetzel RG. Limnology: lake and river ecosystems. 3rd ed. San Diego (CA): Elsevier; 2001.

[2] Directive 91/271/EEC of the European council concerning urban waste-water treatment. Off J Eur Union. 1991;L135;40-52. 
[3] Tchobanoglous G, Burton FL, Stensel HD. Wastewater engineering: treatment and reuse. 4th ed. New York (NY): Mc Graw Hill; 2004.

[4] Jong HH, Oleszkiewicz JA. Effect of cold-temperature shock on nitrification. Water Environ Res. 2007;79:964-968.

[5] Lin Y, Guo M, Shah N, et al. Economic and environmental evaluation of nitrogen removal and recovery methods from wastewater. Bioresour Technol. 2016;215:227238.

[6] Luukkonen T, Sarkkinen M, Kemppainen K, et al. Metakaolin geopolymer characterization and application for ammonium removal from model solutions and landfill leachate. Appl Clay Sci. 2016;119(Part 2):266-276.

[7] Li L, Wang S, Zhu Z Geopolymeric adsorbents from fly ash for dye remoyal from aqueous solution. J. Colloid Interface Sci. 2006;300:52-59.

[8] Khan MI, Min TK, Azizli K, et al. Effective removal of methylene blue from water using phosphoric acid based geopolymers: synthesis, characterizations and adsorption studies. RSC Adv. 2015;5:61410-61420.

[9] Yousef RI, El-Eswed B, Alshaaer M, et al. The influence of using Jordanian natural zeolite on the adsorption, physical, and mechanical properties of geopolymers products. J. Hazard. Mater. 2009;165:379-387.

[10] Liu Y, Yan C, Zhang Z, et al. A facile method for preparation of floatable and permeable fly ash-based geopolymer block. Mater Lett. 2016;185:370-373.

[11] Runtti H, Luukkonen $T$, Niskanen M, et al. Sulphate removal over bariummodified blast-furnace-slag geopolymer J. Hazard. Mater. 2016;317:373-384

[12] Luukkonen T, Runtti H, Niskanen M, et al. Simultaneous removal of Ni(II), $\mathrm{As}(\mathrm{III})$, and $\mathrm{Sb}$ (HI) from spiked mine effluent with metakaolin and blast-furnace-slag geopolymers, Environ. Manage. 2016;166:579-588.

[13] Tang Q, Ge Y, Wang K, et al. Preparation and characterization of porous metakaolin-based inorganic polymer spheres as an adsorbent. Mater Des. 2015;88:1244-1249.

[14] Javadian H, Ghorbani F, Tayebi H, et al. Study of the adsorption of Cd (II) from aqueous solution using zeolite-based geopolymer, synthesized from coal fly ash; kinetic, isotherm and thermodynamic studies. Arabian J. Chem. 2015;8:837-849.

[15] Mužek MN, Svilović S, Zelić J. Kinetic studies of cobalt ion removal from aqueous solutions using fly ash-based geopolymer and zeolite $\mathrm{NaX}$ as sorbents. Sep. Sci. Technol. 2016;51: 2868-2875.

[16] Mužek MN, Svilovic S, Ugrina M, et al. Removal of copper and cobalt ions by fly ash-based geopolymer from solutions-equilibrium study. Desalin. Water Treat. 2016;57:10689-10699. 
[17] Andrejkovicová S, Sudagar A, Rocha J, et al. The effect of natural zeolite on microstructure, mechanical and heavy metals adsorption properties of metakaolin based geopolymers. Appl. Clay. Sci. 2016;126:141-152.

[18] Cheng TW, Lee ML, Ko MS, et al. The heavy metal adsorption characteristics on metakaolin-based geopolymer. Appl. Clay. Sci. 2012;56:90-96.

[19] Chen $\mathrm{Y}$, Tong $\mathrm{Y}$, Pan $\mathrm{R}$, et al. The research on adsorption behaviors and mechanisms of geopolymers on $\mathrm{Sr}^{2+}, \mathrm{Co}^{2+}$ and $\mathrm{Cs}^{+1,2}$ Advanced Mat. Res. 2013;704:313-318.

[20] López FJ, Sugita S, Kobayashi T. Cesium-adsorbent Geopolymer Foams Based on Silica from Rice Husk and Metakaolin. Chem. Lett. 2014;43:128-130.

[21] López FJ, Sugita S, Tagaya M, et al. Metakaolin-based geopolymers for targeted adsorbents to heavy metal ion separation. J. Mater. Sci. Chem. Eng. 2014;2:16-27.

[22] Ge Y, Cui X, Liao C, et al. Facile fabrication of green geopolymer/alginate hybrid spheres for efficient removal of $\mathrm{Cu}(\mathrm{II})$ in water: Batch and column studies. Chem. Eng. J. 2017;311:126-134.

[23] Alshaaer M, Zaharaki D, Komnitsas K. Microstructural characteristics and adsorption potential of a zeolitic tuff-metakaolin geopolymer. Desalin. Water Treat. 2014;56:338-345.

[24] Ge Y, Cui X, Kong Y, et al. Porous geopolymeric spheres for removal of Cu (II) from aqueous solution: Synthesis and evaluation. J. Hazard. Mater. 2015;283:244-251.

[25] Al-Harahsheh MS, Al Zboon K, Al-Makhadmeh L, et al. Fly ash based geopolymer for heavy metal removal: A case study on copper removal. J. Environ. Chem. Eng. 2015;3:1669-1677.

[26] Ge Y, Yuan Y, Wang K, et al. Preparation of geopolymer-based inorganic membrane for removing Ni2+ from wastewater. J. Hazard. Mater. 2015;299:711-718.

[27] Al-Zboon K, Al-Harahsheh MS, Hani FB. Fly ash-based geopolymer for $\mathrm{Pb}$ removal from aqueous solution. J. Hazard. Mater. 2011;188:414-421.

[28] Liu Y, Yan C, Zhang Z, et al. A comparative study on fly ash, geopolymer and faujasite block for Pb removal from aqueous solution. Fuel. 2016;185:181-189.

[29] Davidovits J. Geopolymer Chemistry \& Applications. 3rd ed. Saint-Quentin, France: Institut Geopolymere; 2011.

[30] Luukkonen T. New Adsorption and Oxidation-Based Approaches for Water and Wastewater Treatment [dissertation]. Oulu, Finland: University of Oulu; 2016.

[31] Duxson P, Fernández-Jiménez A, Provis JL, et al. Geopolymer Technology: The Current State of the Art. J Mater Sci. 2007;42:2917-2933. 
[32] Yliniemi J, Nugteren H, Illikainen $\mathrm{M}$ et al. Lightweight Aggregates Produced by Granulation of Peat-Wood Fly Ash with Alkali Activator. Int $\mathrm{J}$ Miner Process. 2016;149: 42-49.

[33] Couto RSDP, Oliveira AF, Guarino AWS, et al. Removal of ammonia nitrogen from distilled old landfill leachate by adsorption on raw and modified aluminosilicate. Environ. Technol. 2016 [cited 4.2.2017]; $\left[\begin{array}{lll}11 & \text { p.]. DOI: }\end{array}\right.$ 10.1080/09593330.2016.1212935

[34] Hedström A. Ion exchange of ammonium in zeolites: a literature review. J. Environ. Eng. 2001;127:673-681.

[35] He H, Xu S, Han R, et al. Nutrient sequestration from wastewater by using zeolite Na-P1 synthesized from coal fly ash. Environ. Technol. 2016 [cited 4.2.2017]; [8 p.]. DOI: 10.1080/09593330.2016.1217061

[36] Ye Z, Wang J, Sun L, et al. Removal of ammonium from municipal landfill leachate using natural zeolites. Environ. Technol. 2015;36:2919-2923.

[37] Finnish Standards Association (SFS). Tests for Mechanical and Physical Properties of Aggregates. Part 6: Determination of Particle Density and Water Absorption. Helsinki, Finland: SFS; 2014. Standard No. SFS-EN 1097-6.

[38] Finnish Standards Association (SFS). Tests for Mechanical and Physical Properties of Aggregates. Part 3: Determination of Loose Bulk Density and Voids. Helsinki, Finland: SFS; 1998. Standard No. SFS-EN ISO 1097-3.

[39] Sips R. On the Structure of a Catalyst Surface. J Chem Phys. 1948;16:490-495.

[40] Ho YS, McKay G. Process Biochem. Pseudo-second order model for sorption processes. 1999;34:451-465.

[41] Fulazzaky MA, Khamidun MH, Omar R. Understanding of mass transfer resistance for the adsorption of solute onto porous material from the modified mass transfer factor models. Chem. Eng. J. 2013;228:1023-1029.

[42] Krom MD. Spectrophotometric Determination of Ammonia: A Study of a Modified Berthelot Reaction using Salicylate and Dichloroisocyanurate. Analyst. 1980;105:305-316.

[43] Provis JL, Duxson P, van Deventer JSJ. The role of particle technology in developing sustainable construction materials. Adv. Powder Technol. 2010;21:2-7.

[44] Saglam N, Say R, Denizli A, et al. Biosorption of inorganic mercury and alkylmercury species on to Phanerochaete chrysosporium mycelium. Process Biochem. 1999;34:725-730.

[45] Charuckyj L, Cooksey P; Zeolite Australia Limited. Process for the removal of suspended and other material from waste water. United States patent US 9,913,012. 2004 Jan 20. 
[46] Wu Z, An Y, Wang Z, et al. Study on Zeolite Enhanced Contact-Adsorption Regeneration-Stabilization Process for Nitrogen Removal. J. Hazard Mater. 2008;156:317-326.

[47] Silva I, Castro-Gomes J, Albuquerque A. Mineral waste geopolymeric artificial aggregates as alternative materials for wastewater-treatment processes: study of structural stability and pH variation in water. J. Mater. Civ. Eng. 2012;24:623-628.

[48] Novais RM, Seabra MP, Labrincha JA. Porous geopolymer spheres as novel pH buffering materials. J. Clean. Prod. 2017;143:1114-1122.

[49] Lide DR, editor. CRC Handbook of Chemistry and Physics. 84th ed. Boca Raton (FL): CRC Press; 2003. 
Table 1. Semi-quantitative energy dispersive spectrum (EDS) analysis of points shown in Figure 1.

\begin{tabular}{cccccccccccc}
\hline $\begin{array}{c}\text { Spectrum } \\
\text { Label }\end{array}$ & P1 & P2 & P3 & P4 & P5 & P6 & P7 & P8 & P9 & P10 & P11 \\
\hline $\mathrm{O}$ & 50.3 & 48.5 & 45.4 & 48.1 & 45.8 & 52.0 & 48.9 & 46.9 & 46.0 & 42.2 & 48.2 \\
$\mathrm{Na}$ & 2.0 & 6.7 & 6.3 & 6.7 & 7.5 & 3.8 & 3.1 & 5.4 & 7.1 & 6.0 & 7.0 \\
$\mathrm{Mg}$ & 0.2 & - & 0.33 & 0.7 & 0.3 & 1.6 & 0.2 & 0.6 & 0.4 & 0.25 & 0.4 \\
$\mathrm{Al}$ & 7.6 & 18.8 & 17.4 & 17.5 & 18.1 & 10.0 & 22.1 & 11.6 & 18.1 & 14.45 & 18.4 \\
$\mathrm{Si}$ & 8.4 & 23.4 & 25.4 & 22.3 & 24.0 & 18.6 & 24.2 & 14.5 & 23.7 & 28.64 & 23.9 \\
$\mathrm{~S}$ & - & - & - & 0.2 & - & 1.2 & - & - & - & - & - \\
$\mathrm{K}$ & 0.5 & 0.8 & 1.6 & 1.9 & 1.7 & 1.7 & 0.7 & 1.1 & 2.5 & 6.39 & 1.0 \\
$\mathrm{Ca}$ & 29.7 & - & 0.3 & 0.3 & 0.2 & 5.3 & - & - & - & - & - \\
$\mathrm{Fe}$ & 1.2 & 1.7 & 3.2 & 2.2 & 2.4 & 4.6 & 0.7 & 20.0 & 2.2 & 2.1 & 1.2 \\
$\mathrm{Cu}$ & - & - & - & - & - & 1.4 & - & - & - & - & - \\
\hline
\end{tabular}


Table 2. Physical properties of metakaolin geopolymer granules (1-4 mm).

\begin{tabular}{lc}
\hline Property & Value \\
\hline Loose bulk density, $\rho_{\mathrm{b}}$ & $932.3 \mathrm{~kg} / \mathrm{m}^{3}$ \\
Percentage of voids, v & $57.9 \%$ \\
Apparent particle density, $\rho_{\mathrm{a}}$ & $2510 \mathrm{~kg} / \mathrm{m}^{3}$ \\
Oven dried particle density, $\rho_{\text {rd }}$ & $2220 \mathrm{~kg} / \mathrm{m}^{3}$ \\
Saturated and surface-dried particle density, $\rho_{\text {ssd }}$ & $2330 \mathrm{~kg} / \mathrm{m}^{3}$ \\
Water absorption, WA & $5.3 \%$ \\
Compressive strength & $63.85 \mathrm{~N}($ average, $\mathrm{n}=11)$ \\
\hline
\end{tabular}


Table 3. Physico-chemical characteristics of synthetic, presedimented and screened wastewaters.

\begin{tabular}{lccc}
\hline Parameter & $\begin{array}{l}\text { Synthetic } \\
\text { wastewater }\end{array}$ & $\begin{array}{l}\text { Pre- } \\
\text { sedimented } \\
\text { effluent }\end{array}$ & $\begin{array}{l}\text { Screened } \\
\text { effluent }\end{array}$ \\
\hline $\mathrm{pH}$ & 6.1 & 7.5 & 7.2 \\
$\mathrm{COD}_{\mathrm{Cr}}[\mathrm{mg} / \mathrm{L}]$ & - & 570 & 642 \\
$\mathrm{TSS}[\mathrm{mg} / \mathrm{L}]$ & - & 419 & 550 \\
$\mathrm{NH}_{4}{ }^{+}[\mathrm{mg} / \mathrm{L}]$ & 32 & 39 & 40 \\
$\mathrm{Al}[\mu \mathrm{g} / \mathrm{L}]$ & - & 8 & 12 \\
$\mathrm{P}[\mu \mathrm{g} / \mathrm{L}]$ & - & 25 & 360 \\
$\mathrm{Ni}[\mu \mathrm{g} / \mathrm{L}]$ & - & 6.0 & 5.8 \\
$\mathrm{Cu}[\mu \mathrm{g} / \mathrm{L}]$ & - & 1.8 & 4.2 \\
$\mathrm{Zn}[\mu \mathrm{g} / \mathrm{L}]$ & - & 150 & 170 \\
$\mathrm{Ca}[\mathrm{mg} / \mathrm{L}]$ & - & 45 & 27 \\
$\mathrm{Mg}[\mathrm{mg} / \mathrm{L}]$ & - & 5.3 & 4.4 \\
$\mathrm{Mn}[\mathrm{mg} / \mathrm{L}]$ & - & 0.2 & 0.1 \\
\hline
\end{tabular}

Table 4. The obtained parameters of isotherm and kinetics models.

\begin{tabular}{lccc}
\hline Parameter & $\begin{array}{c}\text { Synthetic } \\
\text { wastewater }\end{array}$ & $\begin{array}{c}\text { Pre- } \\
\text { sedimented } \\
\text { effluent }\end{array}$ & $\begin{array}{c}\text { Screen } \\
\text { effluen }\end{array}$ \\
\hline Sips isotherm & & & \\
qm, experimental [mg/g] & 32.00 & 16.59 & 26.40 \\
qm, calculated [mg/g] & 31.79 & 17.75 & 28.77 \\
b [L/mg] & 0.10 & 0.14 & 0.17
\end{tabular}




$\begin{array}{lccc}\mathrm{n} & 4.17 & 1.97 & 2.64 \\ \mathrm{R}^{2} & 0.96 & 0.97 & 0.91 \\ \mathrm{RMSE} & 2.53 & 1.08 & 2.86 \\ \mathrm{X}^{2} & 2.29 & 2.45 & 16.18\end{array}$

Pseudo-second order rate equation

$\mathrm{q}_{\mathrm{e}}$, experimental [mg/g]

5.62

5.42

5.62

$\mathrm{q}_{\mathrm{e}}$, calculated [mg/g]

5.27

5.46

5.22

$\mathrm{k}_{\mathrm{p} 2}$ [g/(mg min)]

0.24

0.04

$\mathrm{R}^{2}$

0.97

0.99

0.12

RMSE

0.28

0.16

0.98

RMSE = residual mean square error, $\mathrm{X}^{2}=$ chi square test. 
Table 5. Physico-chemical characteristics of wastewater treated in the pilot experiment three months before the pilot test (as reported by the wastewater treatment plant).

\begin{tabular}{|c|c|c|c|c|}
\hline Parameter & $\begin{array}{l}\text { August } \\
2016 \\
\end{array}$ & $\begin{array}{l}\text { September } \\
2016\end{array}$ & $\begin{array}{l}\text { October } \\
2016\end{array}$ & Average \\
\hline Suspended solids [mg/L] & 3.4 & 1.4 & 3.2 & 2.7 \\
\hline Conductivity $[\mathrm{mS} / \mathrm{m}]$ & 63.6 & 63.0 & 56.6 & 61.1 \\
\hline Alkalinity [mmol/L] & 1.60 & 0.89 & 0.58 & 1.02 \\
\hline $\mathrm{pH}$ & 7.0 & 6.6 & 6.5 & 6.7 \\
\hline Total N [mg/L] & 32 & 34 & 25 & 30 \\
\hline $\mathrm{NH}_{4}^{+}-\mathrm{N}[\mathrm{mg} / \mathrm{L}]$ & 25 & 22 & 23 & 23 \\
\hline $\mathrm{NH}_{4}^{+}[\mathrm{mg} / \mathrm{L}]$ & 32 & 28 & 30 & 30 \\
\hline $\mathrm{NO}_{3}^{-}-\mathrm{N}+\mathrm{NO}_{2}^{-}-\mathrm{N}[\mathrm{mg} / \mathrm{L}]$ & 0.54 & 7.20 & 5.80 & 4.51 \\
\hline Total P [mg/L] & 0.025 & 0.014 & 0.017 & 0.019 \\
\hline Soluble P [mg/L] & $<0.002$ & 0.003 & $<0.002$ & 0.002 \\
\hline $\mathrm{BOD}_{7, \text { atu }}[\mathrm{mg} / \mathrm{L}]$ & $<3$ & $<3$ & & $<3$ \\
\hline $\mathrm{COD}_{\mathrm{cr}}[\mathrm{mg} / \mathrm{L}]$ & $<30$ & $<30$ & $<30$ & $<30$ \\
\hline Al [mg/L] & 0.05 & 0.03 & 0.07 & 0.05 \\
\hline $\mathrm{Fe}[\mathrm{mg} / \mathrm{L}]$ & 0.091 & 0.100 & 0.057 & 0.083 \\
\hline Temperature $\left[{ }^{\circ} \mathrm{C}\right]$ & 14.6 & 15.0 & 13.7 & 14.4 \\
\hline
\end{tabular}




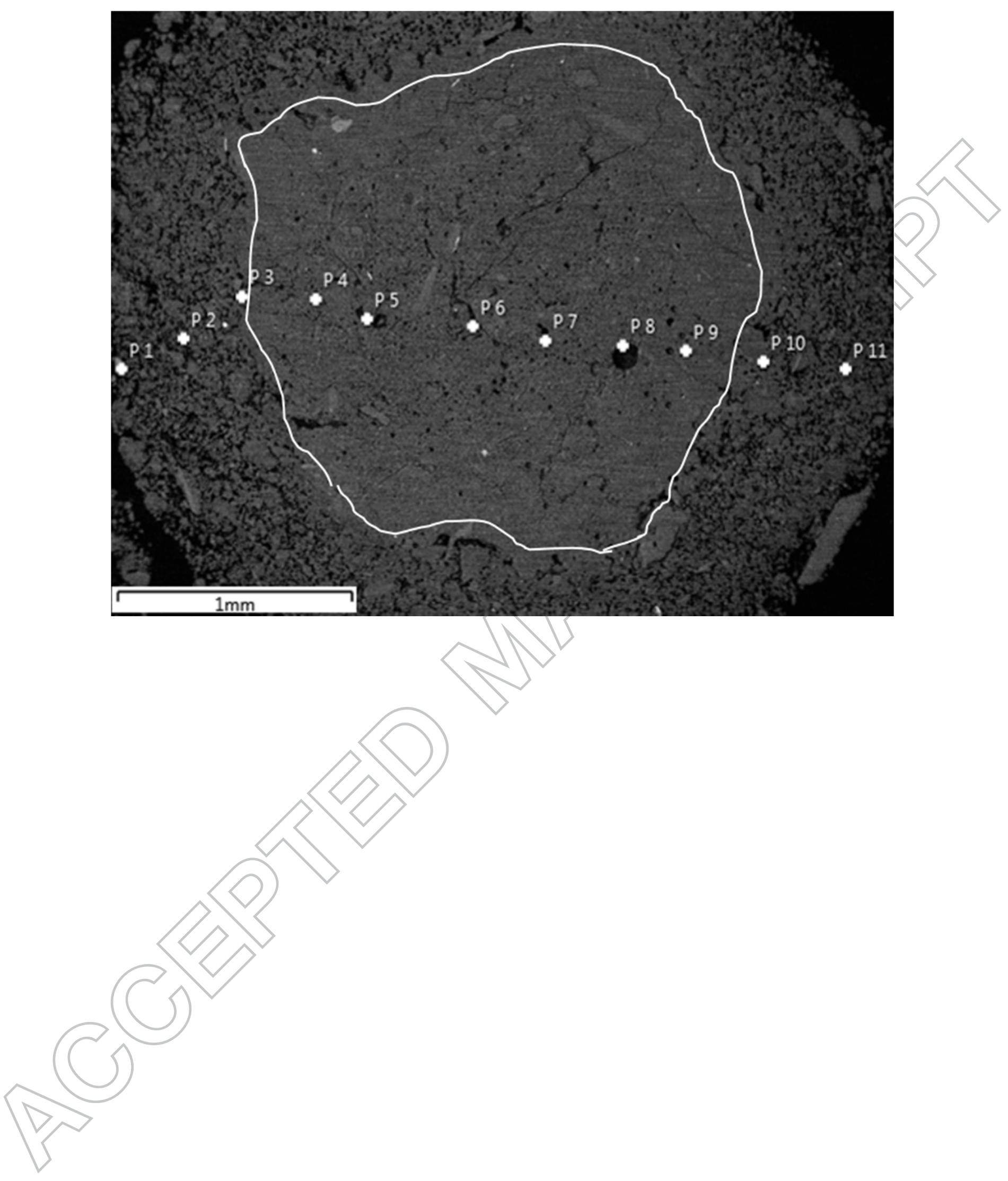



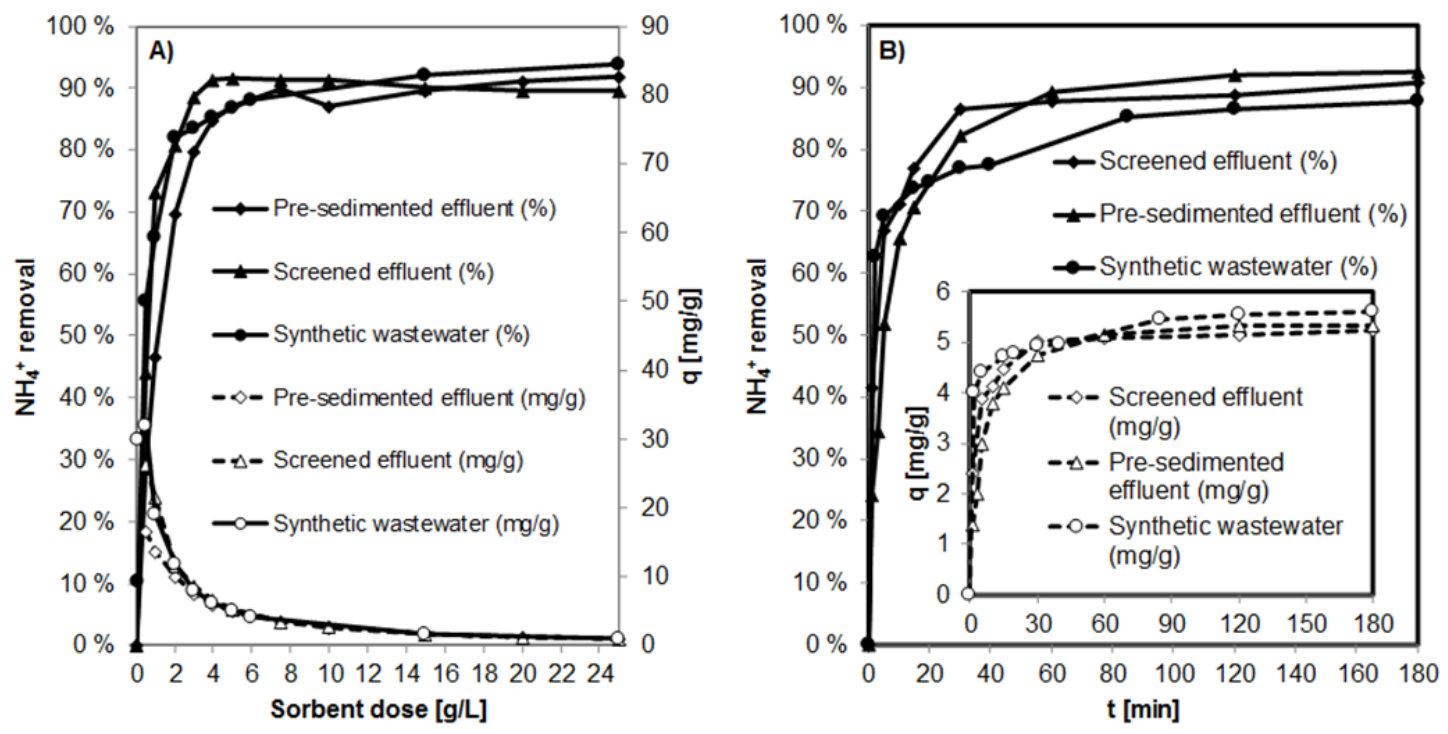

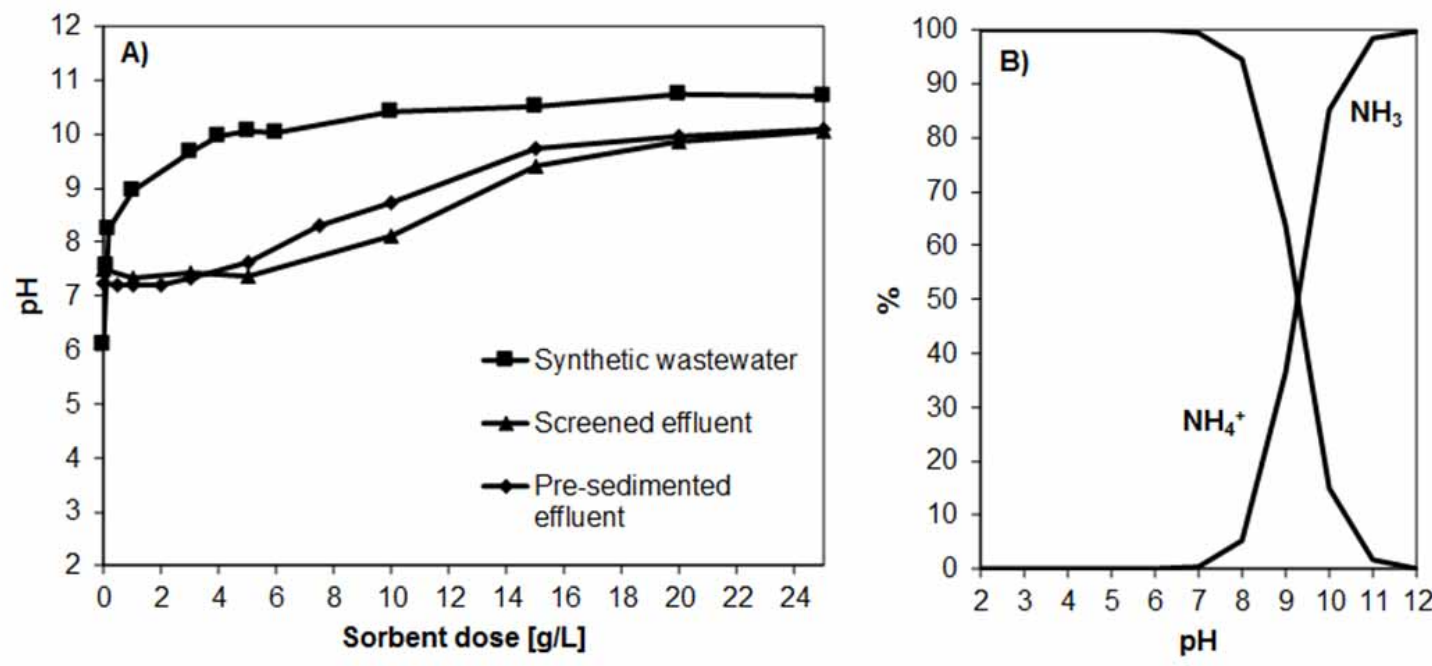

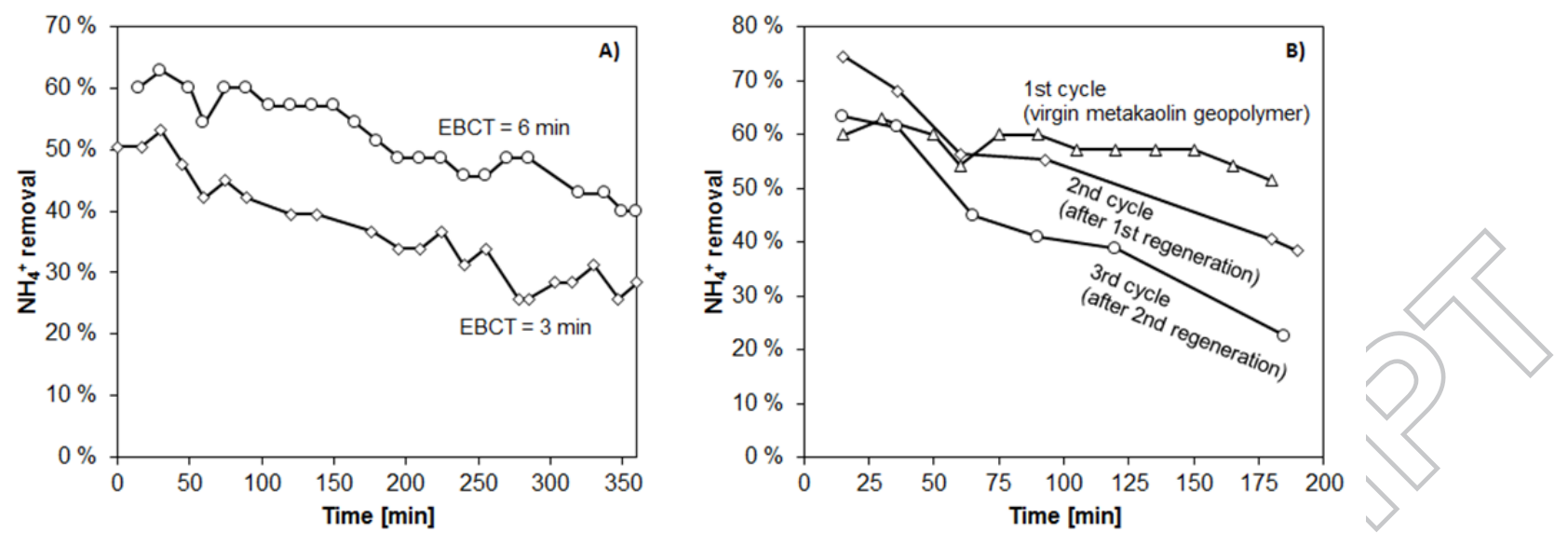

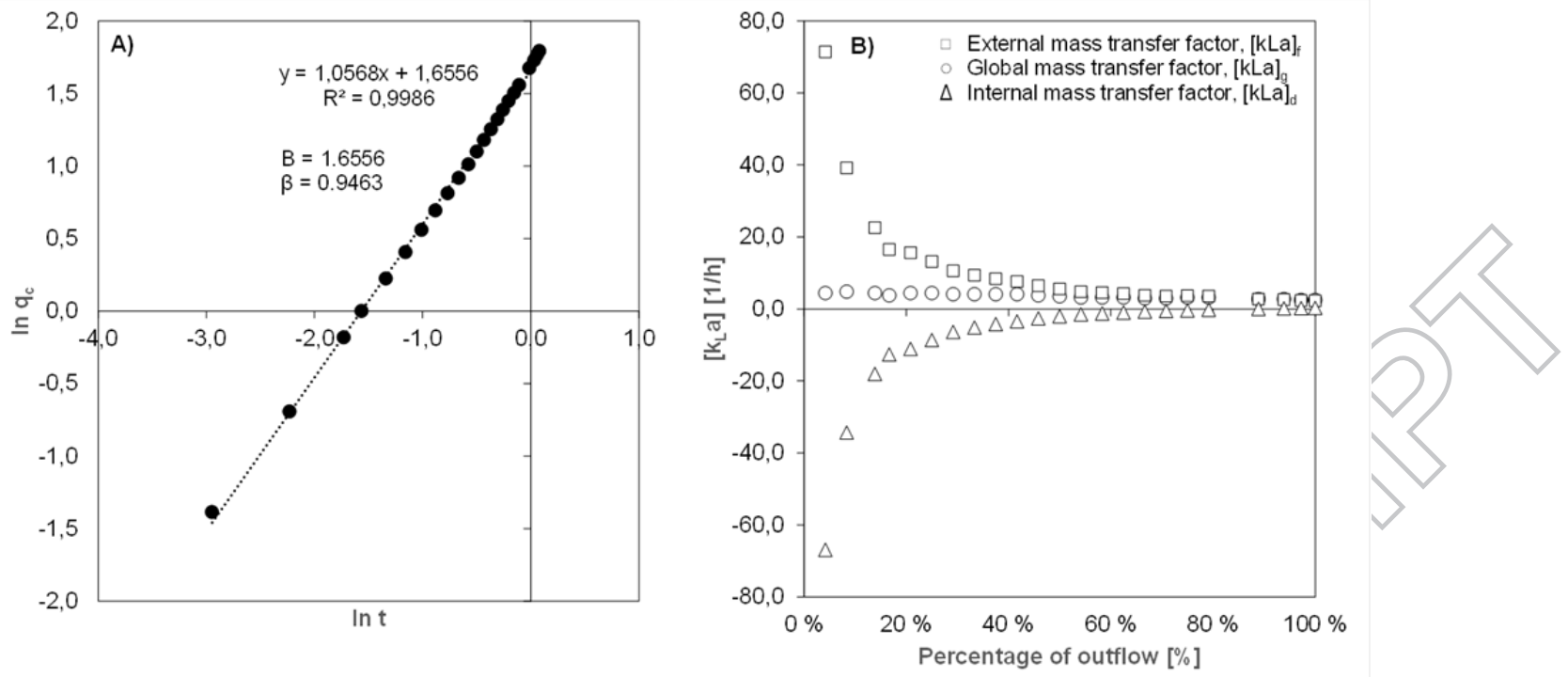


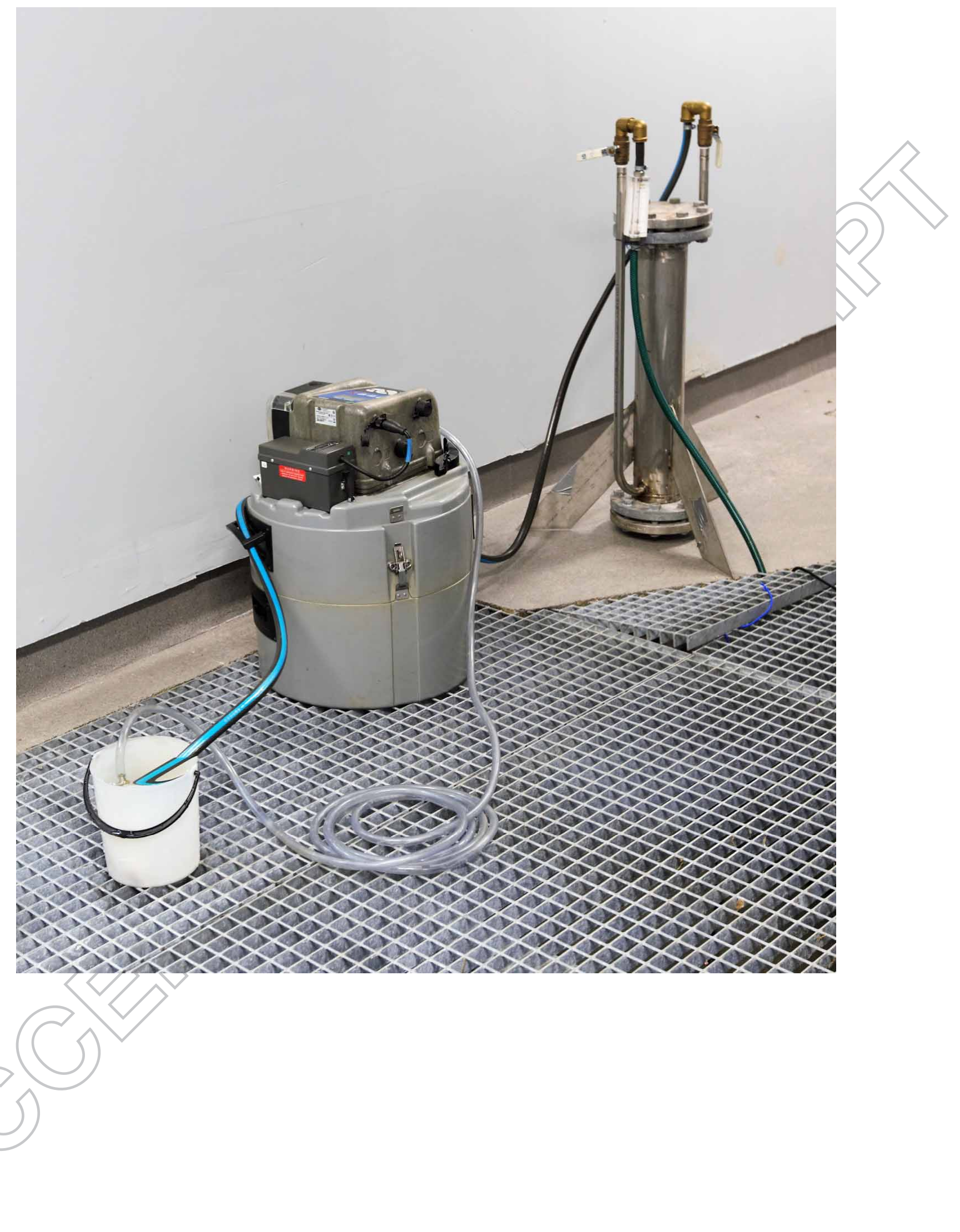




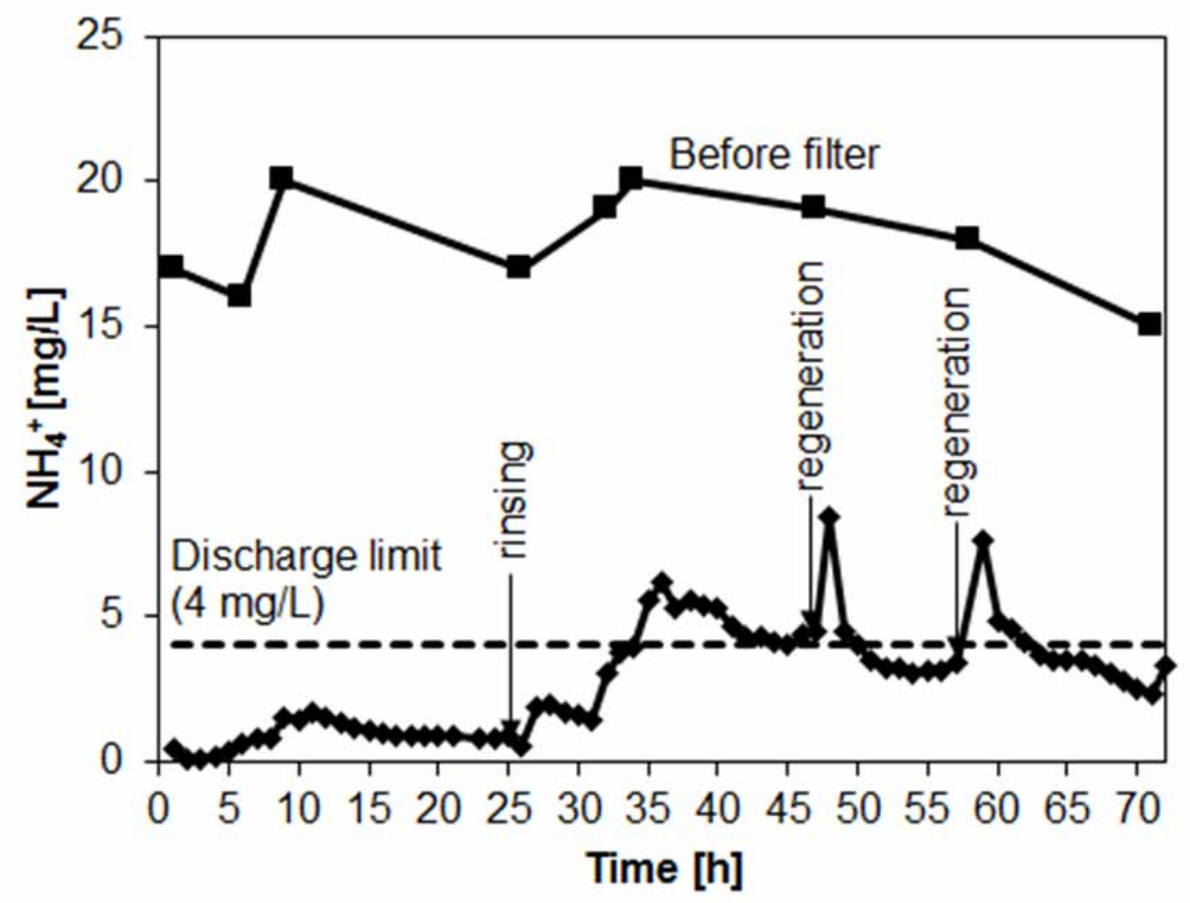




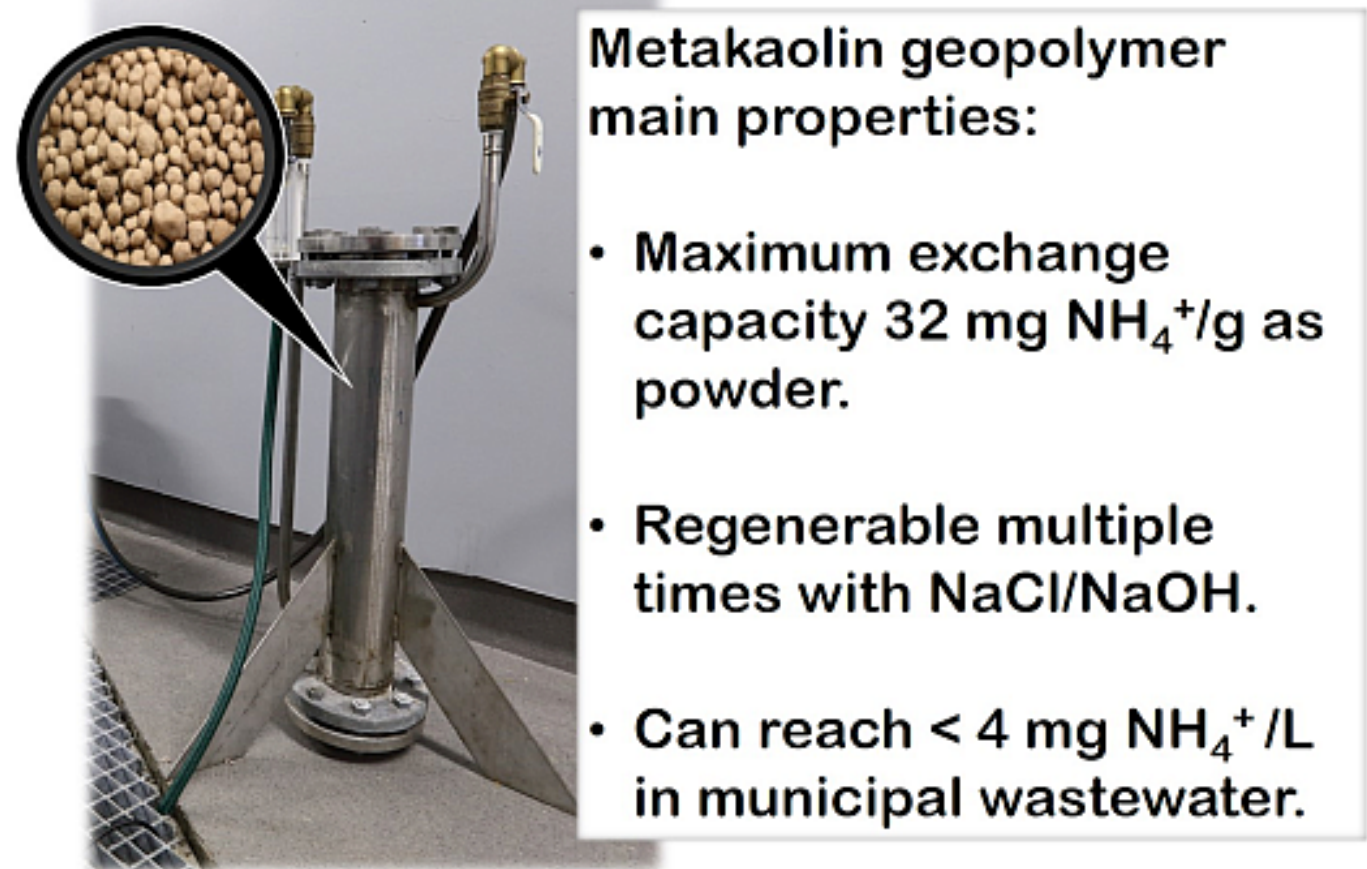

